\title{
EXPERIMENTAL INVESTIGATION OF SHEAR BEHAVIOR OF TWO-SPAN FIBER REINFORCED CONCRETE BEAMS
}

\author{
J. KRASSOWSKA ${ }^{1}$, M. KOSIOR-KAZBERUK ${ }^{2}$
}

\begin{abstract}
Experimental tests were carried out to assess the failure model of steel and basalt fiber reinforced concrete two-span beams. Experimental research was focused on observing the changes in behavior of tested elements in dependence on the ratio of shear reinforcement and type of fiber. The beams had varied stirrup spacing. The steel fiber content was $78.5 \mathrm{~kg} / \mathrm{m}^{3}$ (1.0\% by vol.) and basalt fiber content was $5.0 \mathrm{~kg} / \mathrm{m}^{3}$ ( $0.19 \%$ by vol.). Concrete beams without fibers were also examined. Two-span beams with a cross-section of $120 \times 300 \mathrm{~mm}$ and a length of $4150 \mathrm{~mm}$ were loaded in a five-point bending test. Shear or flexural capacity of tested members was recorded. The effectiveness of both sorts of fibers as shear reinforcement was assessed and the differences were discussed. It was shown that fibers control the cracking process and the values of deflections and strains. Fibers clearly enhance the shear capacity of reinforced concrete beams.
\end{abstract}

Keywords: two-span beam, shear failure, cracking, deflection, fiber reinforced concrete, steel fiber, basalt fiber

\section{INTRODUCTION}

The behavior and design of reinforced concrete members subjected to shear remain the area of much concern in spite of the vast number of experimental works that have been conducted to assess the shear capacity of structural members. The use of traditional stirrups is effective but causes high

\footnotetext{
${ }^{1}$ Msc. Eng., Bialystok University of Technology, Faculty of Civil and Environmental Engineering, Wiejska 45E, 15-351 Bialystok, Poland, e-mail: j.krassowska@pb.edu.pl

${ }^{2}$ DSc., PhD., Eng., Bialystok University of Technology, Faculty of Civil and Environmental Engineering, Wiejska 45E, 15-351 Bialystok, Poland, e-mail: m.kosior@pb.edu.pl
} 
costs associated with the use of reinforcing steel and the cost of assembling them into the structure. When forming beams, short distances between stirrups also cause technological problems with even distribution of aggregates in the concrete, which can lead to cavities and weak bonds between the concrete and reinforcing bars [1]. An alternative solution may be the application of a concrete with dispersed reinforcement in the shear zone beam.

Interest in fiber reinforced concrete structures is growing due to their enhanced toughness [2-5]. Steel fibre reinforced concrete offers many potential benefits as a structural material. Compared to ordinary concrete, steel fiber reinforced concrete has higher flexural tensile strength, and often compression and shear strength, as well as the increased fatigue resistance and impact resistance. The improvement of the mechanical properties of concrete depends on the proper anchoring of the dispersed reinforcement in cement matrix. The use of steel fibers in flexural members ensures an increase in their resistance to cracking, counteracts the effect of shrinkage and prevents the fracture failure of concrete member. The results of research carried out in recent years show a several-fold increase in the fracture energy under bending, shrinkage reduction to $40 \%$ and an increase in modulus of elasticity up to $25 \%$ [6,7]. Steel fibers are mainly used as reinforcements in industrial floors, elements of water structures, in tunnel housings, for repairs and reconstructions of concrete and reinforced concrete members, in prefabricated thin-walled elements.

Several researchers focused on whether steel fibers can be used to replace shear reinforcement in reinforced concrete members [8-10]. Dinh et al. [11] measured the shear capacity of steel fiber reinforced concrete beams with conventional reinforcement, while Susetyo et al. [12] investigated the shear behavior of steel fiber reinforced concrete panels. The fibers can be used to improve the behavior of structure at the ultimate limit state, or to improve service conditions at the serviceability limit state. In the ultimate limit state, the addition of fibers can partially or completely replace the traditional reinforcement for tensile or shear [13, 14].

Many studies carried out over the past 20 years [11, 15-18] that were addressed through experimental and analytical investigation of the shear resistance of steel fiber reinforced concrete resulted in elaboration of the proposals of procedures and standards determining test methods and calculations of structures made of fiber reinforced concrete such as RILEM TC162-TDF [19] and fib Model Code 2010 [20]. The design of fiber reinforced concrete structures is based mainly on the use of residual strength after cracking, provided by dispersed reinforcement. In spite of remarkable development in steel fiber reinforced concrete, this material is not yet widely used in structural applications, because it is still difficult to theoretically predict the structural behavior of fiber 
reinforced concrete members with conventional reinforcement. Thus, it is hard to disseminate design methods that take into account the presence of reinforcement dispersed in concrete.

In addition to steel fibers, other types of fibers have appeared with new properties for which applications are sought. Basalt fibers are a new material that properties are not yet fully researched. The influence of the mechanical properties of basalt fibers on the load-bearing capacity and deformability of concrete members is also not determined. It is known, however, that basalt fibers can work effectively in concrete [21]. The most important advantage of basalt fibers is their $100 \%$ corrosion resistance. In addition, this fiber exhibits high strength and high module performance. Basalt fibers do not need any other additives, thus they are cost effective [22]. According to Sim et al. [23] the fibers have better tensile strength than the E-glass fibers, greater failure strain than the carbon fibers, as well as good resistance to chemical attack, impact load and fire. These features, combined with lower cost, could make basalt fibers a suitable replacement for steel, glass, and carbon fibers in many applications [24]. Detailed discussion of basalt fibers influence on the fracture mechanics parameters can be found in [25]. In the next decade, the use of corrosionresistant composites for construction and strengthening structural elements will grow significantly. It is connected with the policy of sustainable development and natural environment protection. During the manufacturing process of basalt composite, the energy needed to produce fiber reinforcement is several times smaller than in the production of steel, the emission $\mathrm{CO}_{2}$ is also lower [26]. Considering potential applicability of basalt fibers, further experimental studies should be conducted on the use of this type of fibers in concrete for reinforced structures. The recognition of the failure mode of concrete elements with fibers is crucial for the development of design methods that take the presence of dispersed reinforcement in concrete into account.

Extensive work on the effectiveness of using fibers as a replacement of stirrups concerned steel fibers. However, there are no works on the use of other sorts of fibers. The aim of the work was to assess the influence of steel and basalt fibers on the shear capacity of a reinforced concrete member, and to assess the possibility of partial or full replacement of traditional shear reinforcement with fibers. In order to obtain more test results, including tests of shear zones at both external and midrange supports, taking into account different ratio of bending moment to shear force, as well as to reduce the scatter of measurement results, two-span beams were used in the research. 


\section{EXPERIMENTAL INVESTIGATION}

\subsection{CONCRETE MIXTURE COMPOSITION AND SPECIMEN PREPARATION}

Portland cement CEM I 42.5R was used to make concrete for structural elements. The cement content was $300 \mathrm{~kg} / \mathrm{m}^{3}$. The water to cement ratio was equal to 0.5 .

The mixture of sand with a grain diameter up to $2 \mathrm{~mm}$ and coarse aggregate with a grain diameter up to $8 \mathrm{~mm}$ was used. The composition of aggregate was as follows: fraction up to $2 \mathrm{~mm}-51 \%$, fraction $2-4 \mathrm{~mm}-20 \%$ and fraction $4-8 \mathrm{~mm}-29 \%$. The fibers were introduced as a replacement of the adequate portion of aggregate by volume. The modified polycarboxylate and phosphonate based super-plasticizer ( $1 \%$ related to cement mass) was used to minimize fiber clumping and enhance fiber dispersion in concrete.

Two sorts of fibers with different mechanical properties and aspect ratio were used. The geometry and properties of fibers were presented in Table 1. The steel fibers were added to concrete at the content of $78.5 \mathrm{~kg} / \mathrm{m}^{3}$, which gave volume fraction $1.0 \%$ and the basalt fibers were added at the content of $5.0 \mathrm{~kg} / \mathrm{m}^{3}$, which gave volume fraction $0.19 \%$. The content of both sorts of fibers was determined on the basis of previous test results [25, 27] and the fiber manufacturers' recommendations. The effect of fibers on concrete properties was referred to the results obtained for the concrete without fibers.

Table 1. Properties of fibers used

\begin{tabular}{|c|c|c|}
\hline Property & Basalt fibers & Steel fibers \\
\hline Fiber shape & straight & hooked end \\
\hline Length $(\mathrm{mm})$ & 50 & 50 \\
\hline Diameter $(\mathrm{mm})$ & 0.02 & 900 \\
\hline Tensile strength $(\mathrm{MPa})$ & 1680 & 200 \\
\hline Elastic modulus $(\mathrm{GPa})$ & 89 & 7850 \\
\hline Density $\left(\mathrm{kg} / \mathrm{m}^{3}\right)$ & 2660 & \\
\hline
\end{tabular}

The dry aggregate was mixed with steel or basalt fibers respectively, followed by cement. The materials were dry mixed for 2 min before adding water with super-plasticizer. Mixing continued for a further $4 \mathrm{~min}$. The time of mixing was considered sufficient for the proper dispersion of the fibers in the mix without causing a "balling" effect. 
The mechanical properties of concretes with fibers and reference concrete without fibers were determined. The test of compressive strength was carried out in accordance with PN-EN 12390-3 [28] using cubic samples with $100 \mathrm{~mm}$ side size. The flexural tensile strength was determined on specimens of size $100 \times 100 \times 400 \mathrm{~mm}$ according to PN-EN 12390-5 [29]. The elastic modulus was tested in accordance with PN-EN 12390-13 [30] and the splitting tensile strength - according to PNEN 12390-6 [31] using cylindrical samples with a diameter of $150 \mathrm{~mm}$ and a depth of $300 \mathrm{~mm}$.

The specimens were vibrated in moulds and then stored under polyethylene cover for one day. After demoulding, all specimens were cured in water at the temperature of $18 \pm 2{ }^{\circ} \mathrm{C}$ until they were tested.

\subsection{ASSUMPTIONS AND EXPERIMENTAL RESEARCH PROGRAM OF TWO-SPAN BEAMS}

In order to assess the nature of the failure process of reinforced concrete elements with dispersed fiber reinforcement, experimental studies were carried out, in which the emphasis was placed on the identification and analysis of the behavior of tested members depending on the ratio of shear reinforcement and the sort of fibers used.

In the research program, three series of beams differing in the spacing of transversal reinforcement (Fig. 1) were used. Each series consisted of 3 beams with dimensions $120 \times 300 \times 4150 \mathrm{~mm}$.

The cross-section area of main longitudinal reinforcement and shear reinforcement were calculated in accordance with PN-EN 1992-1-1 [32], assuming a load in the form of a concentrated force in the middle of each span. In each test series, the top and bottom reinforcements were identical and consisted of two bars of $\phi 12 \mathrm{~mm}\left(f_{y k}=500 \mathrm{MPa}\right)$. The ratio of longitudinal reinforcement for all tested beams was the same and equaled $0.65 \%$. Beams were reinforced with stirrups (diameter of $\phi 6$ $\mathrm{mm}, f_{y k}=500 \mathrm{MPa}$ ) placed symmetrically with respect to the central support. The increase in the spacing of stirrups in particular series was aimed to demonstrate the possibility of limiting the number of stirrups, whose task was partially taken over by the fiber reinforced concrete. Series A-I beams were reinforced with shear stirrups spacing determined according to PN-EN 1992-1-1 [32]. The ratio of shear reinforcement was equal to $0.10 \%$ and $0.05 \%$, respectively at the central support and outer one. In series A-II, the stirrups had a spacing 50\% as large as determined according to PN-EN 1992-1-1 [32]. 


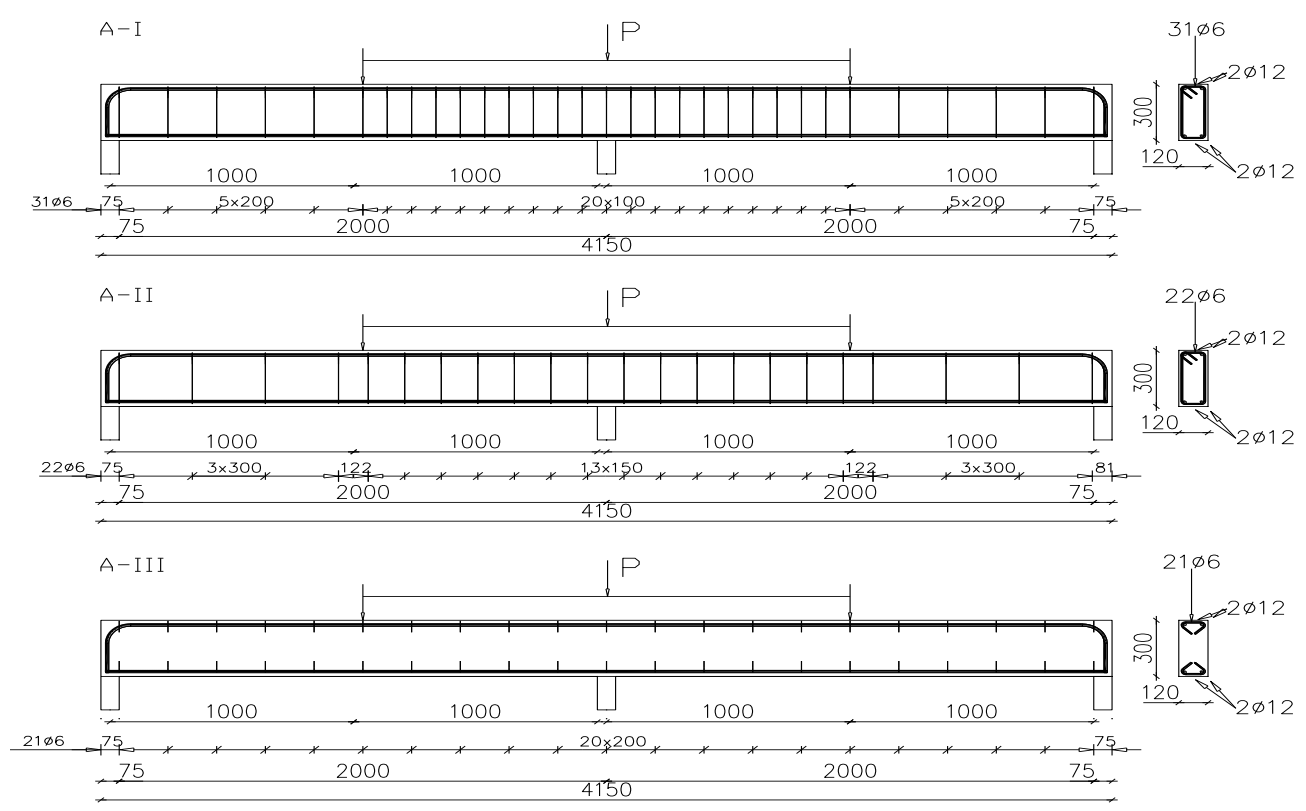

Fig. 1. Schema of reinforcement in beams tested

Beam support points were placed at a distance of $75 \mathrm{~mm}$ from the outer edge of the beams, (Fig. 1) obtaining a length of each span equal to $l_{\text {eff }}=2000 \mathrm{~mm}$. The shear span/effective depth ratio of the tested beams $a_{v} / d$ was equal to 3.5. A description of the series of beam specimens was shown in Table 2.

Table 2. Designation of beam specimens

\begin{tabular}{|c|c|c|c|c|}
\hline Series & $\begin{array}{c}\text { Spacing of stirrups } \\
{[\mathrm{cm}]}\end{array}$ & $\begin{array}{c}\text { Reference beams } \\
\text { (no fibers) }\end{array}$ & $\begin{array}{c}\text { Beams of concrete with } \\
\text { steel fibers }\left(78.5 \mathrm{~kg} / \mathrm{m}^{3}\right)\end{array}$ & $\begin{array}{c}\text { Beams of concrete with } \\
\text { basalt fibers }\left(5.0 \mathrm{~kg} / \mathrm{m}^{3}\right)\end{array}$ \\
\hline A-I & $10 / 20$ & A-I-0 & A-I-WS & A-I-WB \\
\hline A-II & $15 / 30$ & A-II-0 & A-II-WS & A-II-WB \\
\hline A-III & No stirrups & A-III-0 & A-III-WS & A-III-WB \\
\hline
\end{tabular}

During the test the shear and/or flexural capacity of the member was determined. The following values were also measured: 
- mid-span deflection,

- deformation in the compression and tension zone at the level of longitudinal reinforcement,

- development of cracking, determining the value of cracking moment and the system and width of cracks in the beams tested.

The measurement of mid-span deflections was made using inductive sensors with a measuring range of $25 \mathrm{~mm}, 50 \mathrm{~mm}$ and $75 \mathrm{~mm}$ with an accuracy of $0.001 \mathrm{~mm}$. The measurement results were recorded continuously using a diagnostic recorder with a sampling rate of $2 \mathrm{~s}$. Concrete deformation measurement was made using an extensometer. Fig. 2 shows the schema of support and load of beam specimen and the test stand with equipment is presented in Fig. 3.

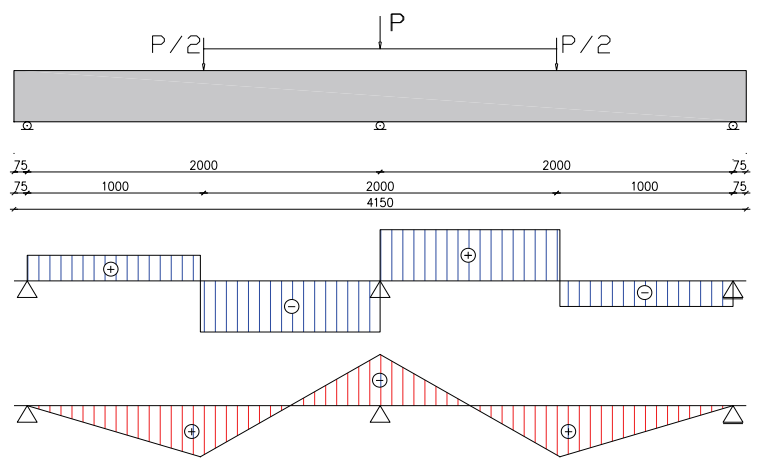

Fig. 2. Schema of support and load of beam

The beams were loaded in a five-point system using a force increase every $10 \mathrm{kN}$, until the element was destroyed. The beams have been loaded three times with a preload to $30 \mathrm{kN}$. The force increase was $10 \mathrm{kN}$ every $30 \mathrm{sec}$. The load was applied using a hydraulic servo control system with a capacity of $500 \mathrm{kN}$ (HYSDOZOK loading system). 


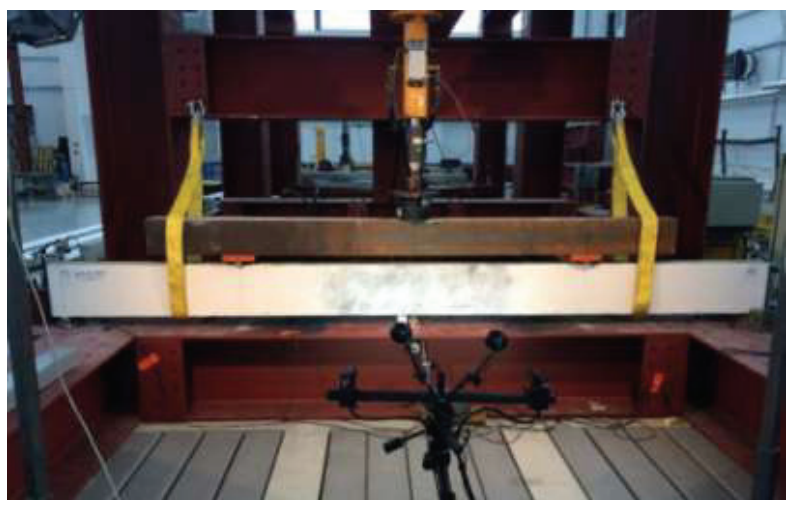

Fig. 3. Test setup with beam specimen

\section{ANALYSIS OF TWO-SPAN BEAMS TEST RESULTS}

\subsection{MECHANICAL PROPERTIES OF CONCRETES}

Table 3 presents the results of mechanical properties test: compressive strength $f_{c m}$, flexural tensile strength $f_{c t m}$, splitting tensile strength $f_{c l}$ and modulus of elasticity $E$ in relation to the fiber content in concrete $\left(V_{f}\right)$.

Table 3. Mechanical properties of concretes (average values and range of accuracy).

\begin{tabular}{|c|c|c|c|c|c|}
\hline $\begin{array}{c}\text { Type } \\
\text { of fiber }\end{array}$ & $\begin{array}{c}V_{f} \\
{\left[\mathrm{~kg} / \mathrm{m}^{3}\right]}\end{array}$ & $\begin{array}{c}f_{c m} \\
{[\mathrm{MPa}]}\end{array}$ & $\begin{array}{c}f_{c t m} \\
{[\mathrm{MPa}]}\end{array}$ & $\begin{array}{c}f_{c l} \\
{[\mathrm{MPa}]}\end{array}$ & $\begin{array}{c}E \\
{[\mathrm{GPa}]}\end{array}$ \\
\hline no fiber & 0 & $52.96( \pm 6.36)$ & $5.14( \pm 0.33)$ & $3.22( \pm 0.39)$ & $33.29( \pm 1.28)$ \\
\hline steel & $78.5(1.0 \%)$ & $52.05( \pm 6.18)$ & $7.21( \pm 1.06)$ & $5.45( \pm 0.51)$ & $33.71( \pm 0.34)$ \\
\hline basalt & $5.0(0.19 \%)$ & $46.24( \pm 5.35)$ & $6.72( \pm 1.22)$ & $4.49( \pm 0.24)$ & $32.86( \pm 2.33)$ \\
\hline
\end{tabular}

The presence of fibers had no significant influence on the average compressive strength $f_{c m}$ of steel fiber reinforced concrete. Concrete with the addition of basalt fibers was characterized by compressive strength lower by approx. $10 \%$ in comparison to the reference one. A slight reduction in compressive strength in this case could be caused by additional aeration of the concrete mix during the introducing basalt fibers and extended mixing process. Concrete can be classified as $\mathrm{C} 25 / 30$. The increase in flexural tensile strength was about $40 \%$ in the case of concrete with steel fibers and $30 \%$ in the case of concrete with basalt fibers. The failure mode of basalt fiber reinforced concrete specimens was brittle as in the concrete without fiber, however, the value of destructive 
force was much higher. Due to the presence of steel or basalt fibers and their different orientations in the concrete mixture, the scatter of test results of the fiber specimens was usually higher than in the case of a reference concrete. The increase in splitting tensile strength was as high as $69 \%$ for steel fibers and $40 \%$ for basalt fibers in comparison to reference concrete. None of the fibers used had any significant effect on the elastic modulus $E$.

\subsection{ANALYSIS OF FAILURE MODE OF BEAMS}

Table 4 shows the values of ultimate load $P_{u l t}$ and their increase $\Delta P_{u l t}$ in comparison to the values of destructive loads for the reference beams (without fibers) $P_{u l t}^{0}$. The value of $P_{u l t}$ was the concentrated load applied from the testing machine, as it was shown in Figs 1 and 2.

Table 4. Ultimate load $P_{u l t}$ and its increase $\Delta P_{u l t}$ in particular series in comparison to series without fibers $P_{u l t}^{0}$

\begin{tabular}{|c|c|c|c|c|c|c|c|c|}
\hline $\begin{array}{c}\text { Type } \\
\text { of fiber }\end{array}$ & \multicolumn{2}{|c|}{ No fibers (W0) } & \multicolumn{4}{|c|}{ Basalt fibers (WB) } & \multicolumn{3}{c|}{ Steel fibers (WS) } \\
\hline Series & $\begin{array}{c}P_{u l t}^{0} \\
{[\mathrm{kN}]}\end{array}$ & Failure mode & $\begin{array}{c}P_{u l t} \\
{[\mathrm{kN}]}\end{array}$ & $\begin{array}{c}\frac{\Delta P_{u l t}}{P_{u l t}^{0}} \\
{[\%]}\end{array}$ & Failure mode & $\begin{array}{c}P_{\text {ult }} \\
{[\mathrm{kN}]}\end{array}$ & $\begin{array}{c}\frac{\Delta P_{u l t}}{P_{u l t}^{0}} \\
{[\%]}\end{array}$ & Failure mode \\
\hline A-I & 222 & F & 229 & 3 & F & 258 & 16 & F \\
\hline A-II & 193 & F+S & 228 & 19 & F+S & 252 & 31 & F+S \\
\hline A-III & 109 & S & 134 & 23 & S & 204 & 87 & S \\
\hline
\end{tabular}

F - failure due to flexural tension, S - failure due to shear

The influence of the dispersed reinforcement on the shear capacity can be determined by comparing the value of ultimate loads in individual series. Series A-I beams have been damaged due to flexure, and the value of ultimate force increased slightly for concrete beams with basalt or steel fibers. In series A-II-WB the value of ultimate force was comparable to the value of the force recorded for A-I-W0 series. It can be concluded that the application of concrete with basalt fibers caused an increase in the ultimate load, despite the number of steel stirrups was reduced. In the case of steel fibers, the average ultimate load in A-II-WS series was even greater than the average load in A-IW0 series.

The shear failure model was obtained in all A-III series beams. The beams were not reinforced with stirrups, the role of stirrups was taken over by the dispersed reinforcement. By using concrete with 
steel fibers, an increase in the ultimate force of two-span beam was achieved by as much as $87 \%$. In the case of beams made of concrete with basalt fibers, the increase in ultimate force was $23 \%$ compared to reference concrete beams. Due to the lower stiffness of basalt fibers, the increase in shear capacity was lower than in the case of steel fibers.

\subsection{CRACKING OF BEAMS}

The development of cracking of selected A-I series beams is shown in Fig. 4. The numbers in the graphs of individual beams indicate the order in which the cracks appeared. As anticipated, their failure occurred due to flexural tension. The addition of steel fiber changed the nature of the beam behavior from brittle to quasi-plastic (ductile).
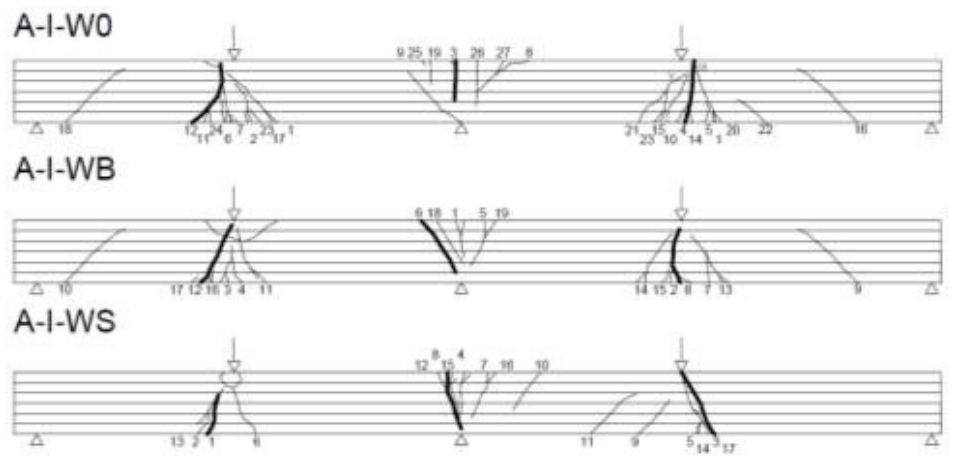

Fig. 4. Crack pattern in A-I series beams (destructive crack was marked with a thick line)

The cracks perpendicular to the longitudinal axis appeared as the first ones in the center of the span of the reference beams (A-I-W0) at a load level of $0.3 P_{u l t}$, whereas in fiber-reinforced concrete beams the first cracks appeared at a load of $0.4 P_{u l t}$. As the load increased, further cracks appeared in the central part of the spans, and they propagated to a depth of $200 \mathrm{~mm}$. In the case of reference concrete beams and basalt fiber reinforced concrete beams, there were also cracks on the central support at the level load of $0.4 P_{u l t}$, while in steel fiber reinforced concrete beams the first cracks at the support zone appeared at a load level of $0.3 P_{u l t}$ and their length achieved approx. $200 \mathrm{~mm}$ from the top edge of the beam. The slow and stable development of perpendicular cracks was observed in all beams. Shear cracks appeared before the plastic hinge occurrence at the central support at load level equal to $0.7 P_{u l t}$ for A-I-W0 series, and at load level of $0.8 P_{u l t}$ for A-I-WB series. In the case 
of beams made of steel fiber reinforced concrete, there were no diagonal cracks at all. The failure of reference concrete beams and basalt fiber reinforced concrete beams occurred due to flexural tension in the middle of the spans and on the central support. The course of the final phase of failure was rather sudden and had a brittle character with a characteristic crack sound. The behavior similar to the behavior of plastic body was observed in the case of A-I-WS series, and with the increase in load, the width of already existing cracks increased, with no new ones appearing. The destruction process was slow.

In beam series with shear cracks, their propagation ran towards the point of concentrated load application and towards the level of longitudinal reinforcement, and then along the longitudinal reinforcement towards the support.
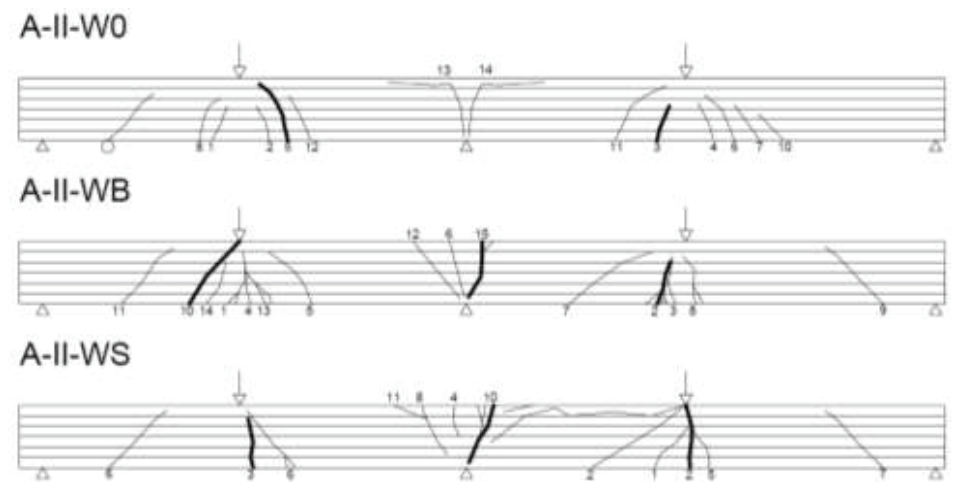

Fig. 5. Crack pattern in A-II series beams (destructive crack was marked with a thick line)

In the case of A-II-W0 and A-II-WB series (Fig. 5), two plastic hinges were observed, firstly in the middle of the spans, and then the failure process took place mainly by shearing at the central support. The destruction process proceeded violently with a characteristic sound. Perpendicular cracks (at the load level of approx. $0.35 P_{u l t}$ ) and longitudinal ones on the upper surface of beams appeared. The straightening of the stirrup hooks (during the destruction phase) and separation of the lateral and bottom cover of reinforcement took place. In the case of A-II-WS beams (Fig. 5), three plastic hinges were observed, first over the central support (load level of $0.8 P_{u l t}$ ), and then in the middle of spans (load level of $0.9 P_{u l t}$ ). The failure process proceeded in a soft manner, and the significant increases in the deflections of the beams' spans at a constant load were observed. 

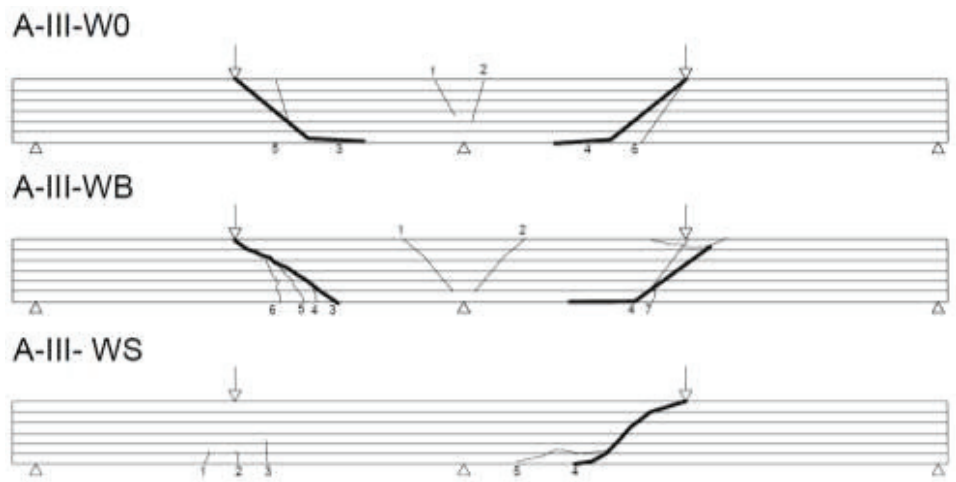

Fig. 6. Crack pattern in A-III series beams (destructive crack was marked with a thick line)

All beams of A-III series were destroyed due to shearing (Fig. 6). The mechanism of crack formation in A-III-W0 and in A-III-WB series beams was the same. The first cracks appeared at the central support $\left(0.4 P_{u l t}\right)$, and then the shear failure of element occurred violently. The beams were destroyed in the zero moment cross-sections (approx. $0.3 \mathrm{l}$ from the central support). The destructive crack width reached $34 \mathrm{~mm}$. In the A-III-WS series elements the first cracks appeared in the spans at a load level of $0.3 P_{u l t}$, followed by a stable development of perpendicular cracks up to 0.8 of the beam depth. At the load level of $0.8 P_{u l t}$, a diagonal crack appeared, causing damage. One of the beams was destroyed by shearing at the central support. In the beams of concrete with steel fiber, the quasi-plastic behavior was observed.

\subsection{SHEAR STRESS ANALYSIS}

The value of shear stress was determined at three supports. The plots in Figs 7 and 8 show the influence of fibers on shear stresses, determined on the basis of the values of support reactions measured during test. Shear stress was determined based on the formula:

$$
v_{u}=V_{u l t} / b d,
$$

where: $V_{u l t}-$ maximum shear force. 
a)

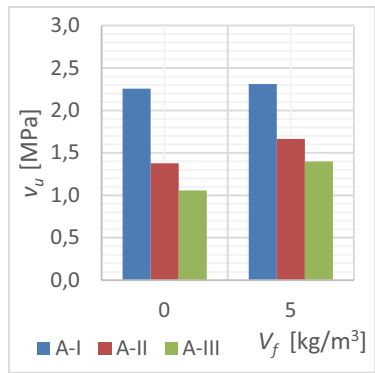

b)

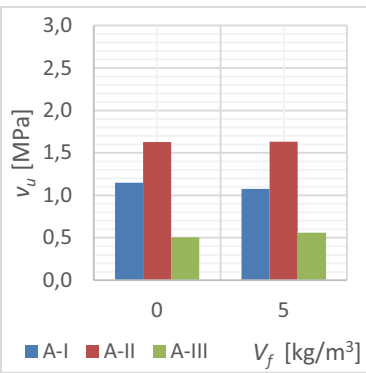

c)

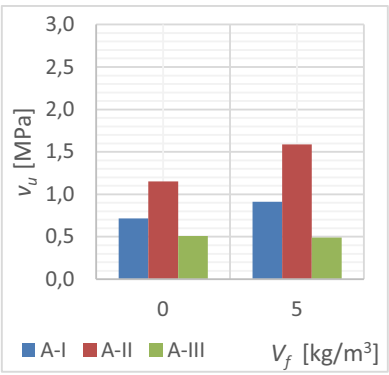

Fig. 7. Shear stress $v_{u}$ in beams made of basalt fiber reinforced concrete at the supports: a) central b) left c) right

Analyzing the A-I series in Fig. 7, one can observe an increase in stresses on the right support, while in the case of the left and central supports, the stress value is constant. The beams in this series were destroyed by flexural tension in one of the spans, and the other span (less damaged) was still able to transfer stresses to the support. In series A-II and A-III, where the failure occurred due to shear, the main shear stress was transferred to the central support. The increase in shear stress at the central support, due to the use of concrete with basalt fibers, was respectively $20 \%$ for A-II series and $30 \%$ for A-III series.

The stress value at the central support in the series A-I (Fig. $8 \mathrm{a}$ ) increased by $24 \%$ when using steel fiber reinforced concrete. Stress value on the outer supports (Figs $8 \mathrm{~b}$ and $8 \mathrm{c}$ ) was significantly reduced due to the formation of plastic hinges in the middle of spans, which was related to the beam operation only at the central support with two cantilevers. In series A-II, where the destruction occurred by shear, the main shear stress was transferred to the central support. The increase in shear stress at the central support for A-II series reached $17 \%$ due to the use of concrete with steel fibers. In the A-III series of beams made of concrete with fibers, it can be noticed that the shear stresses at the outer supports increased three times in comparison to the reference beams without fibers. 
a)

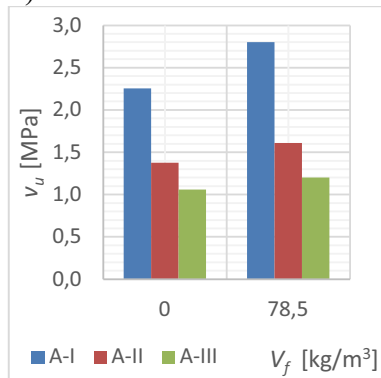

b)

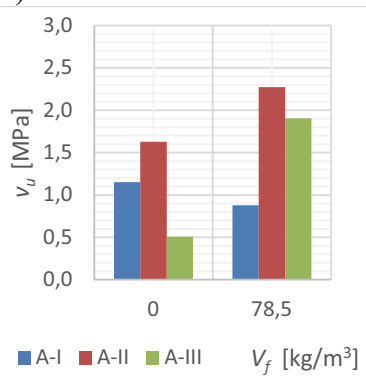

c)

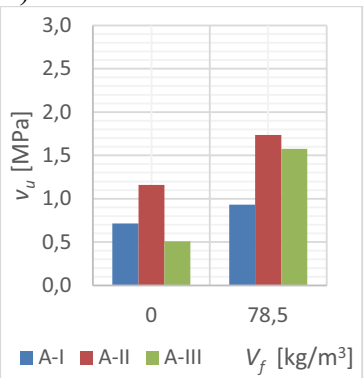

Fig. 8. Shear stress $v_{u}$ in beams made of steel fiber reinforced concrete at the supports: a) central b) left c) right

\subsection{DEFLECTION OF BEAMS}

Figs 9-11 illustrates the load-deflection curves recorded in the middle of the span. The comparison of the mean deflections of reinforced concrete beams allows to determine the effect of the addition of dispersed reinforcement in concrete on deflection. In all series the deflections of beams made of concrete with dispersed reinforcement at the same level of load were smaller than in the reference concrete beams.

The addition of basalt fiber to concrete resulted in a slight reduction of the deflection as compared to reference concrete members in the A-I series, while the addition of steel fibers into concrete caused the reduction of deflection by as much as a half for the same level of loading force. For A-IIWB and A-II-WS series beams the deflections lower by approx. $30-50 \%$ in comparison to A-II-0 series were observed. For the A-III series, with only longitudinal reinforcement without transverse reinforcement, in the case of concrete beams with the addition of steel fiber, the value of deflection was reduced by $30 \%$, and in the case of using concrete with basalt fiber this value decreased by $20 \%$ in relation to reference beams.

Comparison of the curves in Figs 9-11 allows to conclude that an appropriate share of dispersed reinforcement (steel or basalt) in concrete can cause a change in the way the beam failure. The change in the beams' behavior in the quasi-plastic direction is accompanied by an increase in the ultimate force $P_{u l t}$ and a change in the course of the $P$-a curve directly before the beam was damaged, which for the series of steel fiber concrete beams (AI-WS and A-II-WS) became almost linear, and similar to plateau. In the case of concrete beams with basalt fibers, a non-linear relationship was observed with a gradual decrease in the slope of the plot until failure. Both types of 
fibers used caused the reduction of beam deflection due to the tension-stiffening effect. However, the addition of steel fibers in the analyzed content was more effective.

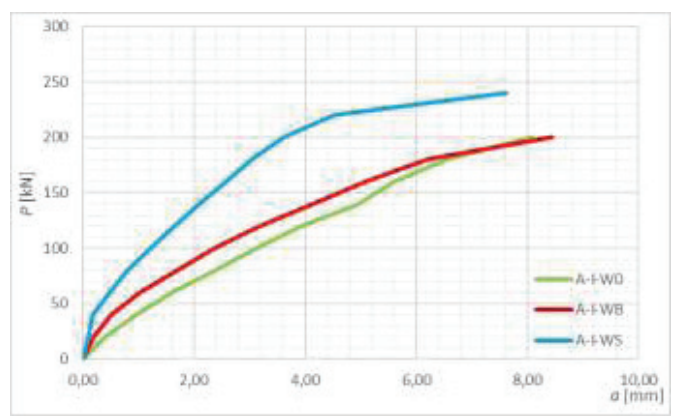

Fig. 9. Load $P$ vs. deflection $a$ curves for A-I series beams

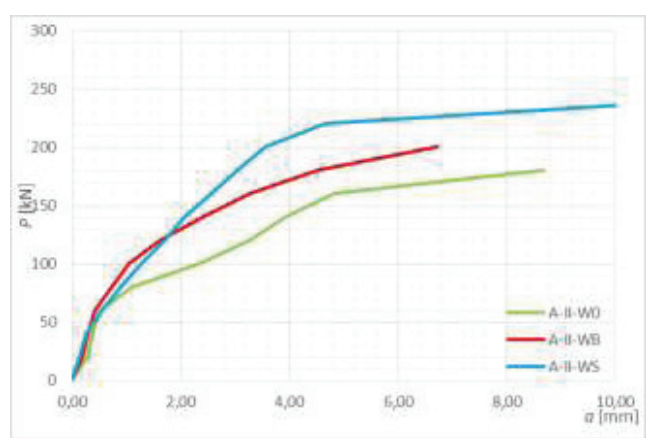

Fig. 10. Load $P$ vs. deflection $a$ curves for A-II series beams

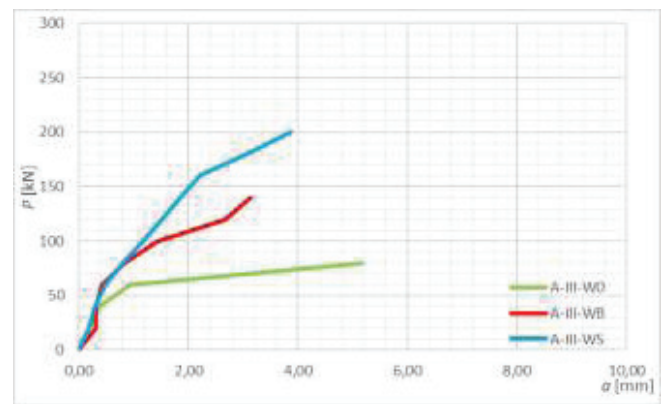

Fig. 11. Load $P$ vs. deflection $a$ curves for A-III series beams 


\subsection{ANALYSIS OF STRAINS IN CONCRETE}

Figs 12-14 present the $P-\varepsilon$ relationship for concrete in the tested beams. The $P-\varepsilon$ relationship was generally non-linear in both compression and tension zones. The elastic deformations of the concrete occurred only in a short segment of the plot, and this segment was the longest in case of beams made of concrete with steel fibers. The strain development in both spans of each beam was similar.

In the tensile zone of A-I series beams, the greatest deformations at the same load level were recorded for beams of concrete with basalt fibers in the whole range of beam test. The difference reached $56 \%$ in comparison to other concrete beams. In the compression zone, the largest deformations were recorded for the reference beams.

The A-II-0 and A-II-WB series beams were characterized by the comparable increase in strains development. The A-II-WS series beams reached the greatest values of strains in the compression zone and the smallest strains in the tensile zone in the stage just before the failure.

a)

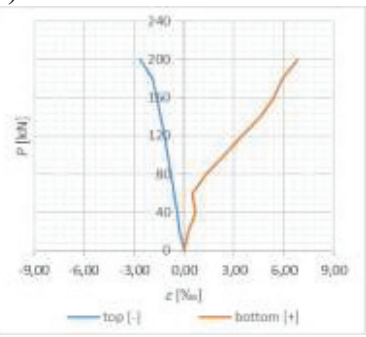

b)

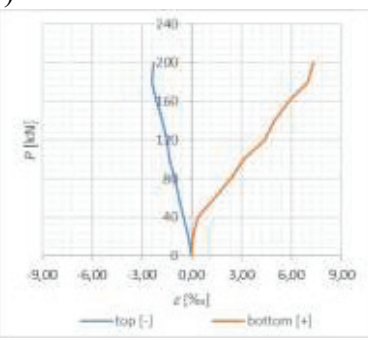

c)

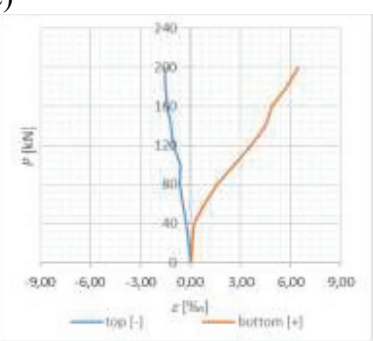

Fig. 12. Comparison of strain development at the level of top and bottom longitudinal reinforcement in beam series a) A-I-W0 b) A-I-WB c) A-I-WS

a)

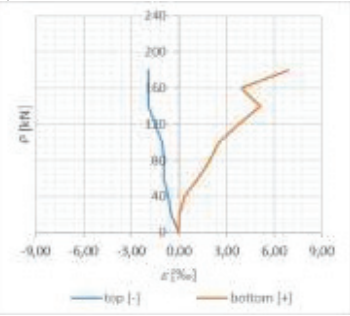

b)

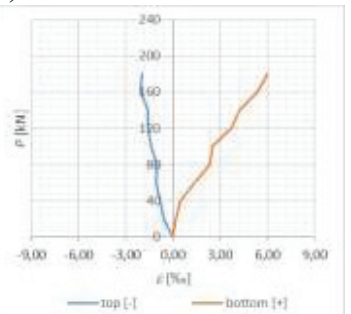

c)

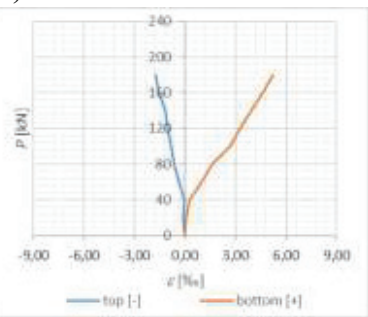

Fig. 13. Comparison of strain development at the level of top and bottom longitudinal reinforcement in beam series a) A-II-W0 b) A-II-WB c) A-II-WS 
a)

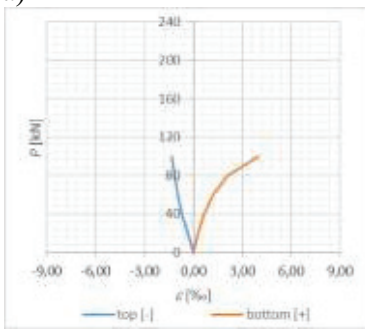

b)

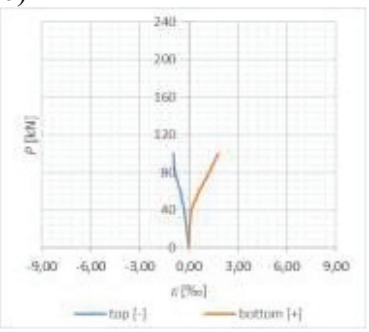

c)

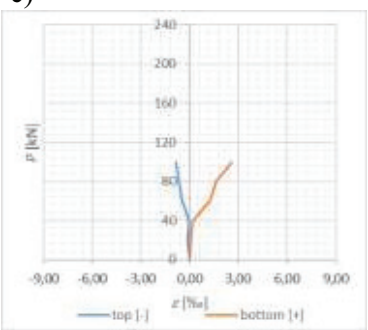

Fig. 14. Comparison of strain development at the level of top and bottom longitudinal reinforcement in beam series a) A-III-W0 b) A-III-WB c) A-III-WS

The smallest deformation values were recorded in the A-III series due to lower destructive loads as compared to the A-I and A-II series. In the A-III series, the strains of concrete in the compressive zone of the reference beams have reached the greatest values. In the tensile zone, the greatest strains at the same load level, were obtained in steel fiber reinforced concrete beams.

\section{CONCLUSIONS}

The research carried out on two-span fiber reinforced concrete beams with different shear reinforcement made it possible to identify and characterize the failure mechanisms of such beams. The assessment of the effectiveness of using steel or basalt dispersed reinforcement in concrete as a replacement of shear reinforcement was made. The following contents of fibers in concrete were considered: $78.5 \mathrm{~kg} / \mathrm{m}^{3}$ (1.0\% by vol.) of steel fibers or $5.0 \mathrm{~kg} / \mathrm{m}^{3}(0.19 \%$ by vol.) of basalt fibers. Steel fibers can effectively replace the minimum ratio of shear reinforcement and the skin reinforcement required to control crack propagation and give visible warning before the structural collapse. Although basalt fibers, due to their geometry and Young's modulus smaller than of steel, are characterized by lower stiffness than steel fibers, their influence on the flexural and shear capacity of the tested beams should be considered significant. Both types of fibers provide concrete toughness that can significantly influence the shear behavior of beams. They do so by basically delaying the occurrence of the shear failure mechanism and, eventually, by altering the collapse from shear to flexure with enhanced load capacity and ductility. The influence of steel fibers on the behavior of beams has already been observed in the case of series A-I with full shear reinforcement. On the other hand, the influence of basalt fibers was fully revealed only during the analysis of A-II series beams with reduced shear reinforcement. Thanks to the use of concrete with steel or basalt fibers, there has been a favorable redistribution of lateral forces by strengthening the shear zone at 
the central support while increasing the shear stress at the outer supports. This was confirmed by the results of the deflection test, the analysis of deformation of concrete in the tensile zone and the changes of shear stress distribution at the beam supports. Both the addition of steel and basalt fibers caused an increase in destructive load as compared to the same beams without dispersed reinforcement. The behavior of fiber reinforced concrete is a combination of effects caused by aggregate and fibers bridging the cracks. The presence of fibers reduced shear deformations at all stages of loading, and this reduction was greater in case of steel fibers. The effect of fibers was particularly significant in preserving the stiffness of the beams, allowing them to carry higher loads until failure occurred. The addition of steel fiber results in greater reduction of deflection in comparison to basalt fiber effect.

The analysis of test results shows that the presence of basalt fibers in concrete should be taken into account when calculating the shear capacity of beams. It is therefore necessary to seek the method of calculating the shear capacity of fiber reinforced concrete beams.

\section{ACKNOWLEDGEMENT}

This research work was financially supported by National Centre for Research and Development, Poland; project ID 245084 and by Ministry of Science and Higher Education; project MB/WBiIŚ/6/2018.

\section{REFERENCES}

1. F.J. Vecchio, "Analysis of shear-critical reinforced concrete beams", ACI Structural Journal 97: 102-110, 2000 .

2. F.A. Farhat, D. Nicolaides, A. Kanellopoulos, B.L. Karihaloo, "High performance fibre-reinforced cementitious composite (CARDIFRC) - Performance and application to retrofitting", Engineering Fracture Mechanics, 74: 151-167, 2007.

3. T. Ponikiewski, M. Pająk, "Experimental investigation on hybrid steel fibers reinforced self-compacting concrete under flexure", Procedia Engineering, 193: 218-225, 2017.

4. J. Michels, R. Christen, D. Waldmann, "Experimental and numerical investigation on postcracking behavior of steel fiber reinforced concrete", Engineering Fracture Mechanics, 98: 326-349, 2013.

5. A. Jansson, M. Flansbjer, I. Lofgren, K. Lundgren, K. Gylltoft, "Experimental investigation of surface crack initiation, propagation and tension stiffening in self-compacting steel-fibre-reinforced concrete", Materials and Structures, 45: 1127-1143, 2012.

6. A.M. Brandt, "Cement based composites: Materials, mechanical properties and performance", $2^{\text {nd }}$ ed., Taylor \& Francis Group, 2009.

7. Z. Owsiak, "Materiały kompozytowe: wybrane zagadnienia (Composite materials: selected problems)", Politechnika Świętokrzyska, Kielce, 2006 (In Polish).

8. R.N. Swamy, H.M. Bahia, "The effectiveness of steel fibers as shear reinforcement", Concrete International, 3 : 35-40, 1985.

9. R. Narayanan, Y.S. Darwish, "Use of steel fibers as shear reinforcement", ACI Structural Journal, 3: 216-227, 1987.

10. A.K. Sharma, "Shear strength of steel fiber reinforced concrete beams", ACI Journal, 4: 624-628, 1986. 
11. H.H. Dinh, G.J. Parra-Montesinos, J.K. Wight, "Shear behavior of steel fibre-reinforced concrete beams without stirrup reinforcement", ACI Structural Journal, 107: 597-606, 2010.

12. J. Susetyo, P. Gauvreau, F.J. Vecchio, "Effectiveness of steel fiber as minimum shear reinforcement", ACI Structural Journal, 108: 488-496, 2011.

13. Q. Chunxiang, I. Patnaikuni, "Properties of high-strength steel fiber-reinforced concrete in bending", Cement and Concrete Composites, 21: 73-81, 1999.

14. F. Minelli, G.A. Plizzari, "On the effectiveness of steel fibers as shear reinforcement", ACI Structural Journal, 3: 379-389, 2013.

15. M. Imam, L. Vandewalle, F. Mortelmans, D. Van Gemert, "Shear domain of fiber-reinforced high-strength concrete beams", Engineering Structures, 9: 738-747, 1997.

16. P. Kannam, V.R. Sarella, R.K. Pancharathi, " Hybrid effects of stirrup ratio and steel fibers on shear behaviour of self-compacting concrete", Archives of Civil Engineering, 64: 145-169, 2018.

17. K.-K. Choi, H.-G. Park, J. Wight, "Shear strength of steel fiber-reinforced concrete beams without web reinforcement", ACI Structural Journal, 104: 12-22, 2007.

18. A. Meda, F. Minelli, G.A. Plizzari, P. Riva, "Shear behavior of steel fiber reinforced concrete beams", Materials and Structures, 38: 343-351, 2005.

19. RILEM TC 162-TDF, "Test and design methods for steel fibre reinforced concrete", Materials and Structures, 36: 560-567, 2003.

20. Model Code 2010, Comité Euro-International du Béton fib (CEB-FIP), 2012.

21. C. High, H. M. Seliem, A. El-Safty, S. H. Rizkalla,"Use of basalt fibers for concrete structures", Construction and Building Materials, 96: 37 - 46, 2015.

22. B. Wei, H. Cao, S. Song, "Environmental resistance and mechanical performance of basalt and glass fibers", Materials Science and Engineering A, 527: 4708-4715, 2010.

23. J. Sim, C. Park, D.Y. Moon, "Characteristics of basalt fibre as a strengthening material for concrete structures", Composites Part B, 36: 504-512, 2005.

24. T.M. Borhan, "Properties of glass concrete reinforced with short basalt fiber", Materials and Design, 42: 265271,2012

25. M. Kosior-Kazberuk, J. Krassowska, "Post-cracking behaviour of basalt fibre reinforced concrete", 6th International Conference on Mechanics and Materials in Design: M2D2015, Ponta Delgada, July 26-30, 2015, 673-682.

26. Resins BDDC et al., LCA Composietbrug Eindrapport (2e versie). Vestiging Rotterdam: VERTROUWELIJK. BECO Groep, Vestiging Rotterdam, 2009.

27. J. Krassowska, M. Kosior-Kazberuk, "Failure mode in shear of steel fiber reinforced concrete beams", 8th Scientific-Technical Conference on Material Problems in Civil Engineering: MATBUD'2018, Cracow, June 25-27, 163: 8, 2018.

28. EN 12390-3 Concrete tests - Part 3: Compressive strength of test specimens, 2011.

29. EN 12390-5 Concrete testing - Part 5: Bending strength of test specimens, 2011.

30. EN 12390-13 Concrete tests - Part 13: Determination of the secant elastic modulus under compression, 2014.

31. EN 12390-6 Concrete tests - Part 6: Tensile splitting strength of test specimens, 2011.

32. EN 1992-1-1 Eurocode 2 - Designing concrete structures - Part 1-1: General rules and rules for buildings, 2010.

\section{LIST OF FIGURES AND TABLES:}

Table 1. Properties of fibers used

Tabela 1. Właściwości stosowanych włókien

Table 2. Designation of beam specimens

Tabela 2. Opis próbek belkowych

Table 3. Mechanical properties of concretes (average values and range of accuracy).

Tabela 3. Właściwości betonów stosowanych do wykonania belek 
Table 4. Destructive load $P_{u l t}$ and their increase $\Delta P_{u l t}$ in particular series in comparison to series with no fibers

Tabela 4. Zestawienie sił niszczących $P_{u l t}$ oraz przyrostu $\Delta P_{u l t}$ w poszczególnych seriach badawczych w porównaniu do serii bez włókien

Fig. 1. Schema of reinforcement in beams tested

Rys. 1. Schemat zbrojenia belek

Fig. 2. Schema of support and load of beam

Rys. 2. Schemat podparcia i obciążenia belek

Fig. 3. Test setup with beam specimen

Rys. 3. Widok stanowiska badawczego z belką

Fig. 4. Crack pattern in A-I series beams (destructive crack was marked with a thick line)

Rys. 4. Schemat zarysowania belek serii A-I (rysę niszczącą zaznaczono grubszą linia)

Fig. 5. Crack pattern in A-II series beams (destructive crack was marked with a thick line)

Rys. 5. Schemat zarysowania belek serii A-II (rysę niszczącą zaznaczono grubszą linia)

Fig. 6. Crack pattern in A-III series beams (destructive crack was marked with a thick line)

Rys. 6. Schemat zarysowania belek serii A-III (rysę niszczącą zaznaczono grubszą linia)

Fig. 7. Shear stress $v_{u}$ in beams made of basalt fiber reinforced concrete at the supports: a) central b) left c) right

Rys. 7. Naprężenia ścinające $w$ belkach $\mathrm{z}$ betonu $\mathrm{z}$ włóknem bazaltowym określone przy podporach a) środkowej b) lewej c) prawej

Fig. 8. Shear stress $v_{u}$ in beams made of steel fiber reinforced concrete at the supports: a) central b) left c) right

Rys. 8. Naprężenia ścinające $w$ belkach $z$ betonu z włóknem stalowym określone przy podporach a) środkowej b) lewej c) prawej

Fig. 9. Load $P$ - deflection $a$ curves for A-I series beams

Rys. 9.Wykres zależności siła $P$ - ugięcie $a$ w serii A-I

Fig. 10. Load $P$ - deflection a curves for A-II series beams

Rys. 10. Wykres zależności siła $P$ - ugięcie $a$ w serii A-II

Fig. 11. Load $P$ - deflection a curves for A-III series beams

Rys. 11. Wykres zależności siła $P$ - ugięcie $a$ w serii A-III

Fig. 12. Comparison of strain development in concrete in beam series a) A-I-W0 b) A-I-WB c) A-I-WS

Rys. 12. Porównanie rozwoju odkształceń w betonie w serii belek a) A-I-W0 b) A-I-WB c) A-I-WS

Fig. 13. Comparison of strain development in concrete in beam series a) A-II-W0 b) A-II-WB c) A-II-WS

Rys. 13. Porównanie rozwoju odkształceń w betonie w serii belek a) A-II-W0 b) A-II-WB c) A-II-WS

Fig. 14. Comparison of strain development in concrete in beam series a) A-III-W0 b) A-III-WB c) A-III-WS

Rys. 14. Porównanie rozwoju odkształceń w betonie w serii belek a) A-III-W0 b) A-III-WB c) A-III-WS 


\title{
BADANIA DOSWIADCZALNE ŚCINANYCH DWUPRZĘSLOWYCH BELEK WYKONANYCH Z BETONU Z DODATKIEM WLÓKIEN
}

\begin{abstract}
Słowa kluczowe: belka dwuprzęsłowa, zniszczenie wskutek ścinania, zarysowanie, ugięcie, beton z dodatkiem włókien,
\end{abstract} włókno stalowe, włókno bazaltowe

\section{STRESZCZENIE:}

Zagadnienia teoretyczne pracy żelbetowych elementów konstrukcyjnych poddanych ścinaniu, jak również problemy projektowania tych elementów, wciąż wymagają wyjaśnienia, pomimo dużej liczby prac eksperymentalnych dotyczących tych problemów. Zastosowanie tradycyjnych strzemion jako zbrojenia na ścinanie jest skuteczne, ale wiąże się z wysokimi kosztami stali zbrojeniowej, a także kosztami ich montażu w konstrukcji. Alternatywnym rozwiązaniem może być zastosowanie w strefie ścinania belki betonu ze zbrojeniem rozproszonym w formie włókien.

Celem badań eksperymentalnych była identyfikacja sposobu niszczenia żelbetowych belek dwuprzęsłowych wykonanych z betonu z włóknami stalowymi lub bazaltowymi. Badania skupiały się na obserwacji zmian zachowania elementów konstrukcyjnych w zależności od ilości zbrojenia na ścinanie (w postaci strzemion) i rodzaju włókien. Zastosowano belki o zróżnicowanym rozstawie strzemion oraz belki bez zbrojenia na ścinanie. Zawartość włókien stalowych w betonie wynosiła $78.5 \mathrm{~kg} / \mathrm{m}^{3}$ (1.0\% obj.), a zawartość włókien bazaltowych $-5.0 \mathrm{~kg} / \mathrm{m}^{3}(0,19 \%$ obj.). Badano również belki referencyjne z betonu bez włókien. Belki dwuprzęsłowe o przekroju 120 x $300 \mathrm{~mm}$ i długości $4150 \mathrm{~mm}$ (efektywna długość przęseł $2000 \mathrm{~mm}$ ) zostały obciążone w warunkach pięciopunktowego zginania. Rejestrowano nośność na ścinanie lub zginanie belek oraz ich odkształcenia. Oceniono i przedyskutowano efektywność obu rodzajów włókien jako alternatywnego zbrojenia na ścinanie. Wykazano, że obecność włókien determinuje proces zarysowania belek oraz znacząco wpływa na wartości ugięć i odkształceń. Pomimo, że włókna bazaltowe charakteryzują się mniejszą sztywnością niż włókna stalowe, ze względu na ich geometrię i wartość modułu Younga mniejszą w porównaniu do włókien stalowych, ich wpływ na nośność na zginanie i ścinanie badanych belek należy uznać za znaczący. Oba rodzaje włókien zmieniają właściwości betonu, co znacząco wpływa na zachowanie się belek w warunkach ścinania. Obecność włókien w betonie powoduje, przede wszystkim, opóźnienie momentu zniszczenia wskutek ścinania, a także zmianę mechanizm zniszczenia ze ścinania na zginanie, z jednoczesnym podwyższeniem nośności i odporności na zarysowanie. Istotny wpływ włókien stalowych zaobserwowano już w przypadku serii belek z pełnym zbrojeniem na ścinanie w postaci strzemion. Natomiast, wpływ włókien bazaltowych ujawnił się dopiero w trakcie analizy belek ze zbrojeniem na ścinanie zredukowanym do połowy. Potwierdzają to zarówno wyniki pomiarów ugięć, jak i analiza odkształcenia betonu w strefie rozciąganej. Wprowadzenie włókien stalowych, jak i bazaltowych przyczyniło się do zwiększenia wartości siły niszczącej w porównaniu do belek bez zbrojenia rozproszonego. Obecność włókien bazaltowych powodowała redukcję odkształceń i ograniczenie ugięć belek w mniejszym stopniu niż wprowadzenie włókien stalowych. Jednakże, wyniki przeprowadzonych badań wskazują na potrzebę poszukiwania sposobów uwzględnienia obecności włókien bazaltowych w procedurach projektowania betonowych elementów zginanych. 